(c) American Dairy Science Association, 2006.

\title{
Association of the OLR1 Gene with Milk Composition in Holstein Dairy Cattle
}

\author{
H. Khatib, ${ }^{1}$ S. D. Leonard, V. Schutzkus, W. Luo, and Y. M. Chang \\ Department of Dairy Science, University of Wisconsin, Madison 53706
}

\begin{abstract}
Oxidized low-density lipoprotein receptor (OLR1) is the major protein that binds, internalizes, and degrades oxidized low-density lipoprotein. The role of OLR1 in lipid metabolism and the results of previous wholegenome scan studies prompted the investigation of OLR1 as a candidate gene affecting milk composition traits. Direct cDNA and genomic sequencing of OLR1 revealed 2 single nucleotide polymorphisms (SNP) in exon 4, $5 \mathrm{SNP}$ in intron 4, and 1 in the $3^{\prime}$ untranslated region (UTR). Four intragenic haplotypes comprising SNP positions 7,160, 7,161, 7,278, 7,381, 7,409, 7,438, 7,512 , and 8,232 were inferred. Haplotype analysis showed that one of the haplotypes was associated with a significant increase in fat yield and fat percentage. Single SNP analysis showed that allele C of SNP 8,232 (in the $3^{\prime}$-UTR) had significant effects on fat yield and fat percentage, whereas SNP 7,160 and 7,161 (in exon 4) had no significant effects. Both single SNP and haplotype analyses indicate that SNP 8,232 in the $3^{\prime}$-UTR is associated with milk fat yield and percentage and it may be in linkage disequilibrium with the functional polymorphism. To provide support for the hypothesis that SNP 8,232 is responsible for OLR1 expression, $O L R 1$ expression levels in individuals bearing different genotypes were assessed. It was found that $O L R 1$ expression was reduced in genotype AA individuals compared with $\mathrm{CC}$ and $\mathrm{AC}$ individuals, suggesting that $\mathrm{A}$ at position 8,232 may be the nucleotide causing decreased OLR1 expression. The $3^{\prime}$-UTR polymorphism found in this study might control translation or stability of OLR1 mRNA.
\end{abstract}

Key words: candidate gene, milk composition, oxidized low-density lipoprotein receptor

\section{INTRODUCTION}

The oxidized form of the low-density lipoprotein (oxLDL) is involved in endothelial cell injury, dysfunc-

Received September 16, 2005.

Accepted November 28, 2005.

${ }^{1}$ Corresponding author: hkhatib@wisc.edu tion, and activation, all of which are implicated in the development of atherosclerosis (Mehta and Li, 1998). It has been shown that oxLDL and its lipid constituents have numerous damaging effects on secretory activities of the endothelium, including induction of apoptosis (Imanishi et al., 2002). The major protein that binds, internalizes, and degrades oxLDL, oxidized LDL receptor 1 (OLR1), was initially identified in bovine aortic endothelial cells by Sawamura et al. (1997). In addition to binding oxLDL, OLR1 removes aged and apoptotic cells from blood circulation (Oka et al., 1998).

The bovine OLR1 gene encodes $270 \mathrm{AA}$ and has $72 \%$ identity to the human protein (Sawamura et al., 1997). Aoyama et al. (1999) determined the structure of human OLR1, and found 6 exons, of which the first 3 corresponded to the N-terminal cytoplasmic, transmembrane, and connecting neck domains, and the last 3 encoded the lectin domain. The genomic sequence of bovine OLR1, recently released by Baylor College of Medicine, contains 5 exons (GenBank accession no. NW_215807).

Several QTL affecting milk production traits have been reported on bovine chromosome 5 near OLR1 (Khatkar et al., 2004). Heyen et al. (1999) reported a putative QTL affecting fat percentage at a position 100 $\mathrm{cM}$ from the centromere in large granddaughter- and daughter-design populations composed of 1,068 sons and 3,264 daughters, respectively. Olsen et al. (2002) reported a QTL affecting fat yield at a position 115 cM from the centromere. Also, Ashwell et al. (2004) reported that a QTL located at $87 \mathrm{cM}$ was associated with fat percentage in a North American Holstein population. Likewise, QTL for other milk production traits in the OLR1 region have also been identified. For example, De Koning et al. (2001) reported that a QTL at $107 \mathrm{cM}$ was associated with milk yield in the Finnish Ayrshire population. Using the same population, Viitala et al. (2003) reported another QTL at $98 \mathrm{cM}$ that was associated with milk yield. A QTL for milk yield was also reported at position $109 \mathrm{cM}$ by Bennewitz et al. (2003). Rodriguez-Zas et al. (2002) reported that a QTL affecting protein yield was located at position $91 \mathrm{cM}$.

Based on the aforementioned studies on the role of human OLR1 in lipid metabolism, including degrada- 
Table 1. Primer sequences used in amplification of cDNA and genomic fragments

\begin{tabular}{|c|c|c|c|}
\hline Primer $^{1}$ (location) & Sequence & Product type & $\begin{array}{l}\text { Length } \\
\text { (bp) }\end{array}$ \\
\hline $\begin{array}{l}\text { OLR5 (exon 1) } \\
\text { OLR6 (exon 5) }\end{array}$ & $\begin{array}{l}\text { ATGACTGTTGATGACCCCAAG } \\
\text { CACTGTGCTCTCAATAGATTCGCCT }\end{array}$ & cDNA & 812 \\
\hline $\begin{array}{l}\text { OLR7 (exon 4) } \\
\text { OLR8 (exon 5) }\end{array}$ & $\begin{array}{l}\text { CTCCTTTGACGCCCCACTT } \\
\text { GGTCCCTGAAGGATACATAC }\end{array}$ & DNA & 670 \\
\hline $\begin{array}{l}\text { OLR3 (exon 5) } \\
\text { OLR4 ( } 3^{\prime} \text {-untranslated region) }\end{array}$ & $\begin{array}{l}\text { AAGGCGAATCTATTGAGAGC } \\
\text { acttctctgaagtcctgca }\end{array}$ & DNA & 270 \\
\hline $\begin{array}{l}\text { OLR9 (exon 4) } \\
\text { OLR10 (exon 5) }\end{array}$ & $\begin{array}{l}\text { GGAATTCATCCAGCAAATGATTGCC } \\
\text { TTGACAACCCCATCCAGAAG }\end{array}$ & $\begin{array}{l}\text { cDNA } \\
\text { (real-time PCR) }\end{array}$ & 89 \\
\hline
\end{tabular}

${ }^{1}$ OLR = Oxidized low-density lipoprotein receptor.

tion of oxLDL, and on previous QTL studies, OLR1 was chosen as a candidate gene for association tests with milk production traits in dairy cattle. In this study several lines of evidence are presented for a single nucleotide polymorphism (SNP) in the $3^{\prime}$ untranslated region (UTR) that is significantly associated with fat yield and fat percentage in milk.

\section{MATERIALS AND METHODS}

\section{Populations and Phenotypic Data}

Semen samples from 29 Holstein sires and their 1,433 sons were obtained from the Cooperative Dairy DNA Repository (CDDR), which is maintained by the USDA Bovine Functional Genomics Laboratory (Beltsville, MD). Daughter yield deviation (DYD) data for milk yield, milk protein and fat yields, milk protein and fat percentages, productive life, and SCS were obtained from the USDA Animal Improvement Programs Laboratory (Beltsville, MD). Samples of DNA from 19 Brown Swiss, 15 Guernsey, 13 Jersey, 12 Bos indicus, 18 Bison bison, and 3 Gaur individuals were included in this study for allele frequency comparisons.

\section{Detection of SNP}

Several SNP were detected in the coding regions of the OLR1 gene by direct sequencing of reverse transcription PCR (RT-PCR) products obtained from a pool of cDNA from 50 animals. Total RNA was extracted from various bovine tissues (adult and fetus, obtained from an abattoir), pooled, and used for RT-PCR amplification as previously described (Khatib et al., 2005). The primers OLR5 and OLR6 (Table 1) were designed to amplify the total cDNA sequence of the gene. The SNP in the genomic sequence were detected by direct sequencing of pooled genomic DNA samples. The DNA pools were constructed from 220 bovine samples and amplified with unlabeled primers. Primers OLR7 and OLR8 (Table 1) were used to amplify genomic DNA sequence of intron 4. Primers OLR3 and OLR4 (Table 1) were used to amplify $270 \mathrm{bp}$ of genomic DNA sequence in the 3'-UTR. The PCR and RT-PCR products were sequenced and SNP were identified by visually inspecting sequence traces.

\section{DNA Genotyping and Haplotype Construction}

Genomic DNA was extracted from semen samples by standard methods using proteinase $\mathrm{K}$ and phenolchloroform. Twenty-nine sires and their 1,433 sons were genotyped in this study. For the polymorphism at position 8,232 (A/C) of OLR1 (GenBank accession no. NW_215807), all sons were genotyped using the restriction enzyme PstI. The digestion products were separated on a 3.0\% agarose gel. The A allele (uncut) was indicated by a band at $270 \mathrm{bp}$ and the $\mathrm{C}$ allele (cut) resulted in a band at $250 \mathrm{bp}$. For the polymorphisms at positions 7,160 and 7,161, individuals were genotyped by direct sequencing. For polymorphisms in intron 4 at positions $7,278,7,381,7,409,7,438$, and 7,512, all 29 sires as well as 4 to 6 heterozygous and 4 to 6 homozygous sons within each sire family were genotyped by direct sequencing using primers OLR7 and OLR8 (Table 1). Intragenic haplotypes were inferred based on the genotypes of sires and their sons. For example, for a sire having the genotypes $\mathrm{C} / \mathrm{T}, \mathrm{A} / \mathrm{G}, \mathrm{T} /$ $\mathrm{G}, \mathrm{A} / \mathrm{G}, \mathrm{C} / \mathrm{T}, \mathrm{C} / \mathrm{G}, \mathrm{C} / \mathrm{G}$, and $\mathrm{A} / \mathrm{C}$, haplotypes C-A-T-AC-C-C-A and T-G-G-G-T-G-G-C were inferred based on one son being homozygous for the haplotype C-A-T-A$\mathrm{C}-\mathrm{C}-\mathrm{C}-\mathrm{A}$ and the other son being homozygous for the haplotype T-G-G-G-T-G-G-C. For individuals with homozygous genotypes, for example, $\mathrm{C} / \mathrm{C}, \mathrm{A} / \mathrm{A}, \mathrm{T} / \mathrm{T}, \mathrm{A} /$ $\mathrm{A}, \mathrm{C} / \mathrm{C}, \mathrm{C} / \mathrm{C}, \mathrm{C} / \mathrm{C}, \mathrm{A} / \mathrm{A}$, the haplotype C-A-T-A-C-C-C-A was inferred. 


\section{Statistical Analyses}

Maternal allele frequencies of $O L R 1$ were estimated following Thaller et al. (2003), in which all sons from homozygous sires and all homozygous sons of heterozygous sires at position 8,232 were used. The allele frequencies were estimated using the formula

$$
\mathrm{P}_{\mathrm{c}}=\frac{\mathrm{n}_{\mathrm{CC}}+\mathrm{n}_{\mathrm{AC}}^{\prime}+\mathrm{n}_{\mathrm{CC}}^{\prime \prime}}{\mathrm{n}_{\mathrm{CC}}+\mathrm{n}_{\mathrm{AA}}+\mathrm{n}_{\mathrm{AC}}^{\prime}+\mathrm{n}_{\mathrm{AA}}^{\prime}+\mathrm{n}_{\mathrm{AC}}^{\prime \prime}+\mathrm{n}_{\mathrm{CC}}^{\prime \prime}}
$$

where $\mathrm{n}_{\mathrm{CC}}$ and $\mathrm{n}_{\mathrm{AA}}$ are the number of homozygous CC and AA sons within heterozygous sires; $\mathrm{n}_{\mathrm{AC}}$ and $\mathrm{n}_{\mathrm{AA}}^{\prime}$ are the number of heterozygous $\mathrm{AC}$ and homozygous AA sons, respectively, from homozygous AA sires; and $\mathrm{n}_{\mathrm{AC}}$ and $\mathrm{n}_{\mathrm{CC}}$ are the numbers of $\mathrm{AC}$ and $\mathrm{CC}$ sons, respectively, of CC sires.

The data were analyzed by an allele substitution model using the PROC GLM function of SAS (SAS Institute, 1999). For single SNP analysis, the model was as follows:

$$
y_{i j}=\mu+\operatorname{sire}_{i}+b x_{i j}+e_{i j}
$$

and for analysis of gene haplotypes, the model was

$$
\mathrm{Y}_{\mathrm{ij}}=\mu+\operatorname{sire}_{\mathrm{i}}+\sum_{\mathrm{k}=1}^{\mathrm{M}-1} \beta_{\mathrm{k}} \mathrm{A}_{\mathrm{ijk}}+\mathrm{e}_{\mathrm{ij}}
$$

where $Y_{i j}$ is the DYD of the trait for son $j$ of sire $i ; \mu$ is the mean; sire $e_{i}$ is the fixed effect of sire $i$; and $e_{i j}$ is the residual. For model [1], $b$ is the regression coefficient representing half of the gene substitution effect (Falconer and Mackay, 1996) and $\mathrm{x}_{\mathrm{ij}}$ is the number of alleles $(0,1$, or 2$)$. For model [2], $\mathrm{A}_{\mathrm{ijk}}=0,1,2$, is the number of copies of haplotype $\mathrm{k}$ present in the ijth individual, where $\mathrm{A}_{0}$ represents the most frequent of $\mathrm{M}$ haplotypes, and the remaining haplotypes are denoted $A_{1}, \ldots A_{k}, \ldots$, $\mathrm{A}_{(\mathrm{M}-1)} ; \beta_{\mathrm{k}}$ are partial regression coefficients corresponding to the effect of haplotype $\mathrm{k}$ as a deviation from the effect of the most frequent haplotype $\left(\mathrm{A}_{0}\right)$, which is set to zero to make the model have full rank (Batra et al., 1989; Weigel et al., 1990; Sharif et al., 1999). Reliability of the son's DYD was incorporated into the models to obtain weighted least squares estimates for the allele effects.

Models [1] and [2] were fitted using weighted least squares, with weights based on reliability (Israel and Weller, 1998). For model [2], significance of associations was determined for each trait separately by an $F$-test on the sum of squares explained by the combined effect of haplotypes. Then, for traits with significant associations, estimates of the effect of individual haplotypes, as a deviation from the effect of the most frequent haplotype, were evaluated for significance.

\section{Real-Time PCR}

Expression levels of $O L R 1$ were evaluated by realtime PCR (Bieche et al., 2000; Karsai et al., 2002) using a standard curve method (Robert et al., 2002). Thirtythree RNA samples obtained from heart tissues (from an abattoir) were extracted using the Qiagen RNeasy kit (Qiagen, Valencia, CA). The primers used for realtime PCR reactions were OLR9 and OLR10 (Table 1). The RNA was reverse transcribed using the iScript cDNA Synthesis kit (BioRad, Hercules, CA). The cDNA synthesis reaction $(20 \mu \mathrm{L})$ included $4 \mu \mathrm{L}$ of $5 \times$ iScript reaction mix, $1 \mu \mathrm{L}$ of iScript reverse transcriptase, and $2 \mu \mathrm{L}$ of RNA. The reaction conditions were performed as recommended by the manufacturer. Expression levels of OLR1 and the housekeeping gene, acidic ribosomal phosphoprotein $(\boldsymbol{P O})$, were evaluated by realtime PCR using a DNA Engine-Opticon 2 Detection System (MJ Research, Watertown, MA). The PCR products were detected with SYBR Green I using iQ SYBR Green Supermix kit (BioRad). Each PCR reaction mix $(25 \mu \mathrm{L}$ ) contained $12.5 \mu \mathrm{L}$ of Supermix (contains dNTP, Taq DNA polymerase, SYBR Green I, and fluorescein), $250 \mathrm{n} M$ of forward primer, $250 \mathrm{n} M$ of reverse primer, and $1.6 \mu \mathrm{L}$ of RT-PCR products. Thermal cycling conditions were $95^{\circ} \mathrm{C}$ for $10 \mathrm{~min}$, followed by 40 cycles of $94^{\circ} \mathrm{C}$ for $30 \mathrm{~s}, 57^{\circ} \mathrm{C}$ for $30 \mathrm{~s}$, and $72^{\circ} \mathrm{C}$ for $30 \mathrm{~s}$, and finally $72^{\circ} \mathrm{C}$ for $5 \mathrm{~min}$. Melting curve analysis and agarose gel electrophoresis were performed after real-time PCR reaction to monitor PCR specificity.

The threshold cycle $\left(\mathrm{C}_{t}\right)$ numbers were determined for the amplified cDNA of the bovine OLR1 mRNA and for the housekeeping gene in each sample during realtime PCR. Standard curves for PCR amplification of cDNAs of OLR 1 and $P O$ genes were constructed using purified PCR products of the mRNA of the 2 genes and 5 serial dilutions of the products. Standard curves were generated by plotting the $\mathrm{C}_{t}$ values (y-axis) against the logarithm of input purified PCR products (x-axis). For each sample, the amounts of $O L R 1$ and $P O$ were determined from the standard curve. Then, the OLR1 amount was divided by the amount of $P O$ to obtain a normalized OLR1 value, expressed as the ratio of OLR1 to PO. The PCR reactions were repeated for samples showing amplification efficiencies lower than $80 \%$.

\section{RESULTS}

The exact location of bovine $O L R 1$ is not known, but based on combined data from different cattle maps we estimated the location of the gene to be in the interval 
Table 2. Intragenic haplotypes at the $O L R 1^{1}$ gene and their frequencies

\begin{tabular}{lll}
\hline Haplotype & Sequence $^{2}$ & Frequency $^{3}$ \\
\hline 1 & C-A-T-A-C-C-C-A & 0.725 \\
2 & C-A-T-C-C-C-C-C & 0.170 \\
3 & C-G-G-G-C-G-G-C & 0.052 \\
4 & T-G-G-G-T-G-G-C & 0.053 \\
\hline
\end{tabular}

${ }^{1} \mathrm{OLR}=$ Oxidized low-density lipoprotein receptor.

${ }^{2}$ Polymorphic site at positions 7,160, 7,161, 7,278, 7,381, 7,409, $7,438,7,512$, and 8,232 .

${ }^{3}$ Haplotype frequencies were estimated based on the maternal alleles of the sons.

of 106 to $108 \mathrm{cM}$ of chromosome 5. In the cattle secondgeneration radiation map, OLR1 was mapped between the markers BMS1658 and BMS772 (http://www. genome.iastate.edu). These 2 markers were mapped in the interval of 106 to $108 \mathrm{cM}$ in the USDA Meat Animal Research Center map (http://www.marc.usda.gov).

\section{Estimation of Allele and Haplotype Frequencies in Cattle Breeds}

Direct sequencing of pooled RT-PCR products for the total coding sequence of $O L R 1$ revealed $2 \mathrm{SNP}$ in exon 4 at positions $7,160(\mathrm{C} / \mathrm{T})$ and $7,161(\mathrm{~A} / \mathrm{G})$. The SNP 7,160 is a missense mutation in which $\mathrm{Thr}$ is replaced by Met, and SNP 7,161 is a synonymous substitution. Direct sequencing of genomic DNA at intron 4 revealed 5 SNP at positions 7,278, 7,381, 7,409, 7,438, and 7,512. Direct sequencing of the $3^{\prime}$-UTR (genomic DNA) of OLR1 revealed $1 \mathrm{SNP}(\mathrm{A} / \mathrm{C})$ at position 8,232. Four intragenic haplotypes (Table 2) comprising positions $7,160,7,161,7,278,7,381,7,409,7,438,7,512$, and 8,232 were inferred in a sample of 633 individuals from the CDDR resource population. Haplotype 1 was inferred by genotyping individuals at position 8,232 ; haplotype 3 was inferred by genotyping individuals at positions 7,160 and 7,161; and haplotypes 2 and 4 were inferred by genotyping at positions 8,232 and 7,161 , respectively. The number of individuals carrying haplotypes $1,2,3$, and 4 were $459,107,33$, and 34 , respectively. Thus, for construction of haplotypes, it was unnecessary to genotype SNP 7,278, 7,381, 7,409, and 7,512 in intron 4 . These SNP were in a conserved haplotype block along with SNP 7,160, 7,161, and 8,232.

For the CDDR Holstein population, 7 sires at SNP 8,232 were homozygous CC, 8 sires were homozygous $\mathrm{AA}$, and 14 sires were heterozygous. The maternal $\mathrm{C}$ allele frequency at SNP 8,232, estimated in 1,433 Holstein sons, was 0.54 (standard error $=0.015$ ). The $\mathrm{C}$ allele frequency was 0.87 in Guernsey and 0.83 in Bos indicus whereas its frequency in Bison bison, Brown Swiss, Jersey, and Gaur was 1.0.
Table 3. Estimates of the allele substitution effects (of allele $\mathrm{C}$ at SNP 8,232) and SE for production and functional traits in the CDDR ${ }^{1}$ population

\begin{tabular}{lrc}
\hline Trait & $\alpha / 2(\mathrm{SE})$ & $P$-value \\
\hline Milk yield, kg & $11.83 \pm 29.24$ & 0.6858 \\
Fat yield, kg & $3.72 \pm 1.07$ & 0.0005 \\
Fat percentage & $0.014 \pm 0.005$ & 0.0033 \\
Protein yield, kg & $0.56 \pm 0.73$ & 0.4391 \\
Protein percentage & $0.001 \pm 0.002$ & 0.6588 \\
Productive life, mo & $0.127 \pm 0.105$ & 0.2255 \\
SCS & $0.006 \pm 0.010$ & 0.5407 \\
\hline
\end{tabular}

${ }^{1} \mathrm{CDDR}=$ Cooperative Dairy DNA Repository.

\section{Effects of Single SNP on Production Traits}

To study the effects of $O L R 1$ variants on production and functional traits, a single SNP analysis was performed only for SNP at positions 7,160, 7,161, and 8,232. Analysis of SNP 7,160 and 7,161 did not show any significant effects on any of the examined traits (data not shown). In contrast, analysis of SNP 8,232 revealed significant effects on both fat yield and fat percentage. Table 3 shows estimates of the allele substitution effects for production and functional traits in 1,433 individuals from the CDDR population. Allele C was associated with significant increases in fat yield $(P=0.0005)$ and fat percentage $(P=0.0033)$. It is worth noting that allele $\mathrm{C}$ did not show any significant unfavorable effects on the other examined traits.

\section{Effects of the OLR1 Haplotypes on Production Traits in the CDDR Holstein Population}

An allele substitution model, in which haplotype 1 was set as a reference haplotype, was used to estimate the effects of OLR 1 haplotypes on milk production and health traits in the Holstein population. Table 4 shows the analysis of the effects of the OLR1 region, which combines information of all haplotypes. The OLR1 region as a whole showed a significant effect on fat percentage $(P=0.0265)$ and fat yield $(P=0.0224)$. In contrast, the $O L R 1$ region did not show significant effects

Table 4. Significance of the effects of the $O L R 1^{1}$ gene region on production and health traits

\begin{tabular}{lll}
\hline Trait & $F$-test & $P$-value \\
\hline Milk yield, kg & 0.39 & 0.7580 \\
Fat yield, kg & 3.22 & 0.0224 \\
Fat percentage & 3.09 & 0.0265 \\
Protein yield, kg & 0.62 & 0.6010 \\
Protein percentage & 0.15 & 0.9320 \\
Productive life, mo & 1.08 & 0.3570 \\
SCS & 0.56 & 0.6410 \\
\hline
\end{tabular}

${ }^{1} \mathrm{OLR}=$ Oxidized low-density lipoprotein receptor. 
Table 5. Estimates of the substitution effects of the $O L R 1^{1}$ haplotypes for milk production and health traits as a deviation from the effect of the most frequent haplotype (haplotype 1)

\begin{tabular}{lcrr}
\hline Trait & Haplotype 2 & Haplotype 3 & Haplotype 4 \\
\hline Milk yield, kg & $10.6 \pm 52.8$ & $22.0 \pm 89.6$ & $-74.6 \pm 77.5$ \\
Fat yield, kg & $5.81 \pm 1.89^{*}$ & $-1.52 \pm 3.21$ & $0.96 \pm 2.78$ \\
Fat percentage & $0.022 \pm 0.008^{* *}$ & $-0.009 \pm 0.014$ & $0.015 \pm 0.012$ \\
Protein yield, kg & $0.73 \pm 1.31$ & $0.36 \pm 2.22$ & $-2.19 \pm 1.92$ \\
Protein percentage & $0.0024 \pm 0.0037$ & $-0.0007 \pm 0.0063$ & $0.0002 \pm 0.0055$ \\
Productive life, mo & $-0.008 \pm 0.179$ & $0.505 \pm 0.316$ & $0.319 \pm 0.281$ \\
SCS & $-0.009 \pm 0.019$ & $-0.024 \pm 0.032$ & $0.021 \pm 0.028$ \\
\hline
\end{tabular}

${ }^{1} \mathrm{OLR}=$ Oxidized low-density lipoprotein receptor.

$* P=0.0022 ; * * P=0.0064$.

on milk yield, protein yield and percentage, productive life, or SCS. Table 5 shows the estimates of the substitution effects of the OLR 1 haplotypes for milk production and health traits as a deviation from the effect of haplotype 1 . Haplotype 2 was associated with a significant increase in fat yield $(P=0.0022)$ and in fat percentage $(P=0.0064)$. Haplotypes 3 and 4 did not show significant effects on any of the examined traits.

The detected effects of haplotype 2, which has $\mathrm{C}$ at position 8,232 , motivated us to estimate the substitution effects of haplotypes 3 and 4 for fat yield and fat percentage as deviations from the effect of haplotype 2. These two haplotypes also have $\mathrm{C}$ at position 8,232 ; hence, significant differences between haplotypes 3 and 4 and haplotype 2 would indicate the presence of additional SNP on haplotype 2 affecting fat yield and fat percentage. For fat yield, haplotypes 3 and 4 did not show significant differences compared with haplotype 2 ; for fat percentage, haplotype 3 showed a suggestive difference $(P=0.0854)$ compared with haplotype 2 .

\section{Expression Analysis of OLR1 Transcripts in Heart Tissues}

To test the expression level of $O L R 1$ in individuals with the $\mathrm{C}$ allele compared with individuals with the A allele at SNP 8,232, DNA samples from 33 individuals were first genotyped using PCR-RFLP and direct genomic sequencing. Twenty individuals were homozygous $\mathrm{CC}, 9$ individuals were heterozygous $\mathrm{AC}$, and 4 individuals were homozygous AA. Then, expression levels of OLR1 in hearts from these individuals were evaluated using real-time quantitative PCR. The level of expression of $O L R 1$ transcripts in relation to $P O$ transcripts was considerably lower in individuals bearing genotype $\mathrm{AA}(O L R 1 / P O$ ratio $=35.4)$ compared with $\mathrm{CC}$ individuals $(O L R 1 / P O$ ratio $=170.5)$. The $O L R 1 / P O$ ratio in heterozygous individuals was 77.4. Thus, $\mathrm{C}$ at position 8,232 in the $3^{\prime}$-UTR may be the functional nucleotide that increases OLR1 expression, and it is in partial linkage disequilibrium with the functional polymorphic site in OLR1 or in some other closely linked gene.

\section{DISCUSSION}

In this study, we report the effect of nucleotide $\mathrm{C}$ at position 8,232 in the 3'-UTR of OLR1, on milk fat yield and milk fat percentage in dairy cattle. Positional comparative candidate gene analysis and previous QTL linkage mapping results were used to select $O L R 1$ as a candidate gene affecting milk composition traits. To search for polymorphic sites in the gene, pools of cDNA extracted from a wide range of cattle tissues and pools of genomic DNA extracted from semen samples were sequenced. Using the pooled sequencing approach, 2 SNP in exon 4, 5 SNP in intron 4, and $1 \mathrm{SNP}$ at position 8,232 in the 3'-UTR were identified. The SNP 7,160 (C/ $\mathrm{T})$ is a missense mutation in which $\mathrm{Thr}$ is replaced by Met, and SNP 7,161 (A/G) is a synonymous mutation.

The first 3 exons of the human $O L R 1$ correspond to the cytoplasmic domain, the transmembrane domain, and the neck domain, whereas exons 4 through 6 encode the lectin-like domain (Aoyama et al., 1999). Chen et al. (2001) conducted series of targeted mutations in the lectin-like domain to identify structures required for oxLDL binding. They found that the lectin-like domain is essential for binding and endocytosis of oxLDL. To test whether the bovine Thr-Met SNP 7,160 found in exon 4 that encodes the lectin-like domain is associated with milk yield and composition traits, we genotyped the 29 Holstein sires of the CDDR population. Genotyping revealed 5 sires heterozygous for SNP 7,160, 8 sires heterozygous for SNP 7,161, and 14 sires heterozygous for SNP 8,232. All sons of the 5 sires heterozygous for SNP 7,160 were genotyped by direct sequencing for both SNP 7,160 and 7,161. In the CDDR population, 4 intragenic haplotypes were identified and tested for association with milk production traits. Only haplotype 2 was associated with a significant increase in fat yield and fat percentage. Thus, it was concluded that the amino acid substitution at position 7,160 (included in haplotype 4) was not responsible for the effects of $O L R 1$ on fat yield and fat percentage.

The results of the single SNP analysis showed that allele C of SNP 8,232 had significant effects on fat yield 
and percentage, whereas SNP 7,160 and 7,161 had no significant effects. In the CDDR population, the correlation between milk yield and fat yield was 0.59 and between protein yield and fat yield it was 0.69 (Khatib et al., 2005). However, SNP 8,232 showed significant effects only on fat yield and fat percentage and not on milk and protein yields, which suggested a specific role of OLR1 in fat metabolism in tissues other than the mammary gland.

The results show that the effects of haplotype 2 were not significantly different from the effects of haplotypes 3 and 4 . Because haplotypes 2, 3, and 4 all included allele $\mathrm{C}$ at SNP 8,232, the results of single SNP analysis and haplotype analysis strongly indicate that SNP 8,232 in the $3^{\prime}$-UTR might be linked to milk fat yield and percentage. To search for other SNP in the 3'-UTR, $790 \mathrm{bp}$ of genomic DNA from all 29 sires was sequenced, but no additional SNP were identified.

To provide support for the hypothesis that SNP 8,232 is responsible for the $O L R 1$ effects, the levels of $O L R 1$ expression were assessed in individuals bearing different genotypes. Expression of OLR1 was reduced in AA individuals compared with $\mathrm{CC}$ and $\mathrm{AC}$ individuals, suggesting that the $\mathrm{A}$ at position 8,232 may be the nucleotide causing decreased $O L R 1$ expression, or it may be in linkage disequilibrium with a nearby functional SNP. Heart tissues were chosen for this study because of the role of OLR1 in lipid metabolism in cardiac muscle tissues. Initial identification of OLR1 was in bovine aortic endothelial cells where it is highly expressed compared with other tissues (Sawamura et al., 1997). There are 2 origins of milk lipids; one is fatty acid synthesis de novo in the mammary gland and the other is uptake of blood lipids by the mammary gland (Dils, 1986). Fatty acids imported to the mammary gland reflect the composition of fatty acids synthesized by other organs and released into the blood (Dils, 1986). Thus, the association of allele $\mathrm{C}$ with a significant increase in milk fat yield and milk fat percentage might reflect the high expression of OLR1 synthesized in hearts of CC individuals and released into the blood.

It is noteworthy that 2 independent studies on the human gene reported that a SNP $(\mathrm{C} / \mathrm{T})$ in the $3^{\prime}$-UTR at position 1,073 (GenBank accession no. NM_002543) was associated with Alzheimer's disease. LuedeckingZimmer et al. (2002) reported that, among 3 SNP identified in OLR1, the $3^{\prime}$-UTR polymorphism showed the most significant association with Alzheimer's disease. Moreover, they showed that the $\mathrm{C}$ allele at this position had a higher affinity for binding regulatory proteins compared with the T allele. Lambert et al. (2003) presented additional evidence that the $3^{\prime}$-UTR polymorphism was associated with Alzheimer's disease. Using electrophoretic mobility shift assays, they found that the $\mathrm{C}$ allele was associated with higher binding affinity of nuclear proteins. In addition, they showed that the expression level of OLR1 was lower in individuals bearing CC genotypes compared with $\mathrm{CT}$ and TT individuals. The location of SNP 1,073 in the human gene is 190 nucleotides downstream from the stop codon and the location of SNP 8,232 in the bovine gene is 223 nucleotides downstream from the stop codon.

The exact mechanism by which the bovine $O L R 1$ variants affect milk fat yield and milk fat percentage is not clear. However, given that OLR1 is a receptor for oxLDL and that it is expressed abundantly in heart tissues, it might directly affect the metabolism of oxLDL, which in turn affects fat metabolism. In fact, the hypothesis that human $O L R 1$ variants might be involved in heart disease was tested in two independent studies. Mango et al. (2003) showed that the $3^{\prime}$-UTR SNP was associated with higher risk of developing acute myocardial infarction. Chen et al. (2003) reported association of the 3 '-UTR SNP with coronary artery disease. Moreover, using an electrophoretic mobility shift assay, they found that the $3^{\prime}$-UTR SNP affects the binding of a putative transcription factor in an allele-specific manner. Thus, the 3 '-UTR SNP that affected milk fat yield and milk fat percentage in the current study might affect mRNA stability or translation of the OLR1 transcript as was predicted for the human gene (Chen et al., 2003). There is growing evidence that 3 '-UTR sequences are involved in the regulation of gene expression and they can control stability of mRNA, polyadenylation, rates of translation, nuclear transport, and gene silencing (Conne et al., 2000). Recently, Oliver et al. (2005) reported that a 3'-UTR polymorphism in the $G p c 3$ gene, a candidate gene chosen based on QTL studies, affects growth in mice.

Estimation of allele frequencies of $O L R 1$ in different cattle breeds provided additional support for the hypothesis that SNP 8,232 is linked to fat yield and percentage. It has long been known that Bison bison, and the Brown Swiss, Jersey, and Guernsey breeds have higher milk fat percentage than does the Holstein breed. Surprisingly, in this study it was found that the frequency of the $\mathrm{C}$ allele of SNP 8,232-the allele associated with an increase in fat yield and fat percentage in this Holstein population-was $54 \%$ in the Holsteins, whereas its frequency in Bison bison, Brown Swiss, and Jersey populations was $100 \%$, and its frequency in Guernsey was 87\%.

\section{CONCLUSIONS}

In conclusion, this study presents several lines of evidence that OLR1 SNP 8,232 is linked to milk fat yield and percentage: i) significant effect of SNP 8,232; 
ii) significant effect of haplotype 2 , which differs from haplotype 1 only at position 8,232 ; iii) differences in expression of $\mathrm{AA}, \mathrm{AC}$, and $\mathrm{CC}$ genotypes at 8,232, primarily due to haplotypes 1 and 2 , which differ only at 8,232 ; iv) high frequency of allele $\mathrm{C}$ in breeds with high fat percentage; v) lack of effect of SNP 7,160 and 7,161; and vi) effects of SNP 1073 in the 3'-UTR of the human gene.

We cannot completely exclude the possibility that the observed effects could be caused by linkage disequilibrium with other functional SNP in control regions of $O L R 1$ or by linkage disequilibrium with other nearby genes.

\section{ACKNOWLEDGMENTS}

This research was supported by Hatch grant \#WIS04736 from the University of Wisconsin-Madison. We thank the USDA Bovine Functional Genomics Laboratory for providing semen samples.

\section{REFERENCES}

Aoyama, T., T. Sawamura, Y. Furutani, R. Matsuoka, M. C. Yoshida, H. Fujiwara, and T. Masaki. 1999. Structure and chromosomal assignment of the human lectin-like oxidized low-density-lipoprotein receptor-1 (LOX-1) gene. Biochem. J. 339:177-184.

Ashwell, M. S., D. W. Heyen, T. S. Sonstegard, C. P. Van Tassell, Y. Da, P. M. VanRaden, M. Ron, J. I. Weller, and H. A. Lewin. 2004. Detection of quantitative trait loci affecting milk production, health, and reproductive traits in Holstein cattle. J. Dairy Sci. 87:468-475.

Batra, T. R., A. J. Lee, and J. S. Gavora. 1989. Class I alleles of the bovine major histocompatibility system and their association with economic traits. J. Dairy Sci. 72:2115-2124.

Bennewitz, J., N. Reinsch, C. Grohs, H. Leveziel, A. Malafosse, H. Thomsen, N. Xu, C. Looft, C. Kuhn, G. A. Brockmann, M. Schwerin, C. Weimann, S. Hiendleder, G. Erhardt, I. Medjugorac, I. Russ, M. Forster, B. Brenig, F. Reinhardt, R. Reents, G. Averdunk, J. Blumel, D. Boichard, and E. Kalm. 2003. Combined analysis of data from two granddaughter designs: A simple strategy for QTL confirmation and increasing experimental power in dairy cattle. Genet. Sel. Evol. 35:319-338.

Bieche, I., C. Nogues, V. Paradis, M. Olivi, P. Bedossa, R. Lidereau, and M. Vidaud. 2000. Quantitation of hTERT gene expression in sporadic breast tumors with a real-time reverse transcriptionpolymerase chain reaction assay. Clin. Cancer Res. 6:452-459.

Chen, M., S. Narumiya, T. Masaki, and T. Sawamura. 2001. Conserved C-terminal residues within the lectin-like domain of LOX1 are essential for oxidized low-density-lipoprotein binding. Biochem. J. 355:289-296.

Chen, Q., S. E. Reis, C. Kammerer, W. Y. Craig, S. E. LaPierre, E. L. Zimmer, D. M. McNamara, D. F. Pauly, B. Sharaf, R. Holubkov, C. N. Bairey Merz, G. Sopko, F. Bontempo, and M. I. Kamboh. 2003. Genetic variation in lectin-like oxidized low-density lipoprotein receptor 1 (LOX1) gene and the risk of coronary artery disease. Circulation 107:3146-3151.

Conne, B., A. Stutz, and J. D. Vassalli. 2000. The 3' untranslated region of messenger RNA: A molecular 'hotspot' for pathology? Nat. Med. 6:637-641.

De Koning, D. J., N. F. Schulmant, K. Elo, S. Moisio, R. Kinos, J. Vilkki, and A. Maki-Tanila. 2001. Mapping of multiple quantita- tive trait loci by simple regression in half-sib designs. J. Anim. Sci. 79:616-622.

Dils, R. R. 1986. Comparative aspects of milk fat synthesis. J. Dairy Sci. 69:904-910.

Falconer, D. S., and T. F. C. Mackay. 1996. Introduction to Quantitative Genetics. 4th ed. Longman Scientific and Technical, New York, NY.

Heyen, D. W., J. I. Weller, M. Ron, M. Band, J. E. Beever, E. Feldmesser, Y. Da, G. R. Wiggans, P. M. VanRaden, and H. A. Lewin. 1999. A genome scan for QTL influencing milk production and health traits in dairy cattle. Physiol. Genomics 1:165-175.

Imanishi, T., T. Hano, T. Sawamura, S. Takarada, and I. Nishio. 2002. Oxidized low density lipoprotein potentiation of Fas-induced apoptosis through lectin-like oxidized-low density lipoprotein receptor-1 in human umbilical vascular endothelial cells. Circ. J. 66:1060-1064.

Israel, C., and J. I. Weller. 1998. Estimation of candidate gene effects in dairy cattle populations. J. Dairy Sci. 81:1653-1662.

Karsai, A., S. Muller, S. Platz, and M. T. Hauser. 2002. Evaluation of a homemade SYBR green I reaction mixture for real-time PCR quantification of gene expression. Biotechniques 32:790-796.

Khatib, H., E. Heifetz, and J. C. Dekkers. 2005. Association of the protease inhibitor gene with production traits in Holstein dairy cattle. J. Dairy Sci. 88:1208-1213.

Khatkar, M. S., P. C. Thomson, I. Tammen, and H. W. Raadsma. 2004. Quantitative trait loci mapping in dairy cattle: Review and meta-analysis. Genet. Sel. Evol. 36:163-190.

Lambert, J. C., E. Luedecking-Zimmer, S. Merrot, A. Hayes, U. Thaker, P. Desai, A. Houzet, X. Hermant, D. Cottel, A. Pritchard, T. Iwatsubo, F. Pasquier, B. Frigard, P. M. Conneally, M. C. Chartier-Harlin, S. T. DeKosky, C. Lendon, D. Mann, M. I. Kamboh, and P. Amouyel. 2003. Association of 3'-UTR polymorphisms of the oxidised LDL receptor 1 (OLR1) gene with Alzheimer's disease. J. Med. Genet. 40:424-430.

Luedecking-Zimmer, E., S. T. DeKosky, Q. Chen, M. M. Barmada, and M. I. Kamboh. 2002. Investigation of oxidized LDL-receptor 1 (OLR1) as the candidate gene for Alzheimer's disease on chromosome 12. Hum. Genet. 111:443-451.

Mango, R., F. Clementi, P. Borgiani, G. B. Forleo, M. Federici, G. Contino, E. Giardina, L. Garza, I. E. Fahdi, R. Lauro, J. L. Mehta, G. Novelli, and F. Romeo. 2003. Association of single nucleotide polymorphisms in the oxidised LDL receptor 1 (OLR1) gene in patients with acute myocardial infarction. J. Med. Genet. 40:933-936.

Mehta, J. L., and D. Y. Li. 1998. Identification and autoregulation of receptor for OX-LDL in cultured human coronary artery endothelial cells. Biochem. Biophys. Res. Commun. 248:511-514.

Oka, K., T. Sawamura, K. Kikuta, S. Itokawa, N. Kume, T. Kita, and T. Masaki. 1998. Lectin-like oxidized low-density lipoprotein receptor 1 mediates phagocytosis of aged/apoptotic cells in endothelial cells. Proc. Natl. Acad. Sci. USA 95:9535-9540.

Oliver, F., J. K. Christians, X. Liu, S. Rhind, V. Verma, C. Davison, S. D. Brown, P. Denny, and P. D. Keightley. 2005. Regulatory variation at glypican-3 underlies a major growth QTL in mice. PLoS Biol. 3:e135.

Olsen, H. G., L. Gomez-Raya, D. I. Vage, I. Olsaker, H. Klungland, M. Svendsen, T. Adnoy, A. Sabry, G. Klemetsdal, N. Schulman, W. Kramer, G. Thaller, K. Ronningen, and S. Lien. 2002. A genome scan for quantitative trait loci affecting milk production in Norwegian dairy cattle. J. Dairy Sci. 85:3124-3130.

Robert, C., S. McGraw, L. Massicotte, M. Pravetoni, F. Gandolfi, and M. A. Sirard. 2002. Quantification of housekeeping transcript levels during the development of bovine preimplantation embryos. Biol. Reprod. 67:1465-1472.

Rodriguez-Zas, S. L., B. R. Southey, D. W. Heyen, and H. A. Lewin. 2002. Interval and composite interval mapping of somatic cell score, yield, and components of milk in dairy cattle. J. Dairy Sci. 85:3081-3091.

SAS Institute. 1999. SAS User's Guide. SAS OnlineDoc, Version 8. SAS Inst., Inc., Cary, NC.

Sawamura, T., N. Kume, T. Aoyama, H. Moriwaki, H. Hoshikawa, Y. Aiba, T. Tanaka, S. Miwa, Y. Katsura, T. Kita, and T. Masaki. 
1997. An endothelial receptor for oxidized low-density lipoprotein. Nature 386:73-77.

Sharif, S., B. A. Mallard, B. N. Wilkie, J. M. Sargeant, H. M. Scott, J. C. Dekkers, and K. E. Leslie. 1999. Association of the bovine major histocompatibility complex DRB3 (BoLA-DRB3) with production traits in Canadian dairy cattle. Anim. Genet. 30:157-160.

Thaller, G., W. Kramer, A. Winter, B. Kaupe, G. Erhardt, and R. Fries. 2003. Effects of DGAT1 variants on milk production traits in German cattle breeds. J. Anim. Sci. 81:1911-1918.
Viitala, S. M., N. F. Schulman, D. J. de Koning, K. Elo, R. Kinos, A. Virta, J. Virta, A. Maki-Tanila, and J. H. Vilkki. 2003. Quantitative trait loci affecting milk production traits in Finnish Ayrshire dairy cattle. J. Dairy Sci. 86:1828-1836.

Weigel, K. A., M. E. Kehrli Jr., M. J. Stear, and D. H. Kelley. 1990. Association of class I bovine lymphocyte antigen complex alleles with health and production traits in dairy cattle. J. Dairy Sci. 73:2538-2546. 